\title{
MY “LITTLEFIGHT” WITH MIEROSŁAWSKI
}

In a letter to Konstancja Górska written at the beginning of 1880 Norwid asks: "And where were you then, Mrs Konstancja? - I think in Warsaw, whereas I and the late Mierosławski would fight a little - and in the end he was fighting these Prussians, without army, marshals or Napoleon III" (PWsz X, 142). The letter regards, among other things, Norwid's translation of Dante's The Divine Comedy. He worked on some passages during his imprisonment in Berlin from late June to late July $1846 .{ }^{1}$ The question "Where were you then?" refers to this period, although perhaps not necessarily to his imprisonment but to the time when the poet was most probably visiting the region of Poznań. It remains uncertain whether he met with the "general of failure" (as Mierosławski was hailed by the authors of Kalendarium życia i twórczości Cypriana Norwida). There is no information about either Norwid's itinerary or the places he visited. ${ }^{2}$ Nevertheless, he certainly had the occasion to feel the atmosphere of a budding insurrection and witness the preparations, perhaps even partaking in them.

Zofia Trojanowiczowa suggests that Norwid's 1846 stay in Greater Poland could have begun somewhere between the beginning of the year and the second half of June. ${ }^{3}$ Mierosławski arrived in Poznań from Paris on 31 December 1845. On 8 January he left for Kraków, where he arrived on 12 January and stayed until 27 January. On the next day, however, he was already back in Poznań, where on 11

${ }^{1}$ For more information about Norwid's Berlin imprisonment see: Z. TROJANOwICZOWA, Norwid w więzieniu berlińskim, [in:] Z. Trojanowiczowa, Romantyzm. Od poetyki do polityki, eds. A. Artwińska, J. Borowczyk, P. Śniedziewski, Kraków 2010, pp. 191-213.

2 Z. Trojanowiczowa, Z. DAmbeK, Kalendarium życia i twórczości Cypriana Norwida, Poznań 2007, vol. 1, p. 209.

${ }^{3}$ Z. Trojanowiczowa, Na wielkopolskim tropie Norwida, [in:] Z. Trojanowiczowa, Romantyzm, p. 163. 
February he went to the nearby town of Świniary. On 12 February he was arrested there after being denounced by count Henryk Poniński. ${ }^{4}$ If Norwid in fact met Mierosławski, this must have taken place somewhere between early January and 12 February 1846. It is unclear whether this happened. The two could have met in Poznań or somewhere along the way between Poznań and Kraków (in Świniary or Pudliszki). Perhaps they met in some manor, where Mierosławski would stay for the night. Perhaps they journeyed together for some time. Mierosławski travelled under a different name and Norwid may have also had false documents. ${ }^{5}$ Perhaps the phrase "fight a little" refers to such issues. Most probably this question will never be settled.

It is also uncertain (though conceivable) that the phrase "fight a little" could refer to a possible meeting. Would it involve some kind of "fighting"? The phrase does not necessarily suggest participation in preparations for the failed uprising, but can refer to a polemic with the general. Trojanowiczowa takes this into account, writing: "Due to Norwid's aversion to Mierosławski's plan, one could regard it [the "fighting"] as a polemic with him, opposition to his activities." If this is to be taken into account, however, we would have to assume that some kind of a meeting between the poet and the general must have taken place. Alternatively, Norwid could refer in the letter to Górska not to Mierosławski himself but to the very idea of an insurrection, which the general represented. ${ }^{7}$

Adam Krechowiecki, who characterizes Norwid's political views in the book O Cypryanie Norwidzie, quotes the following passage from the 1861 diary of Bohdan Zaleski:

Ludwik Mierosławski was at home; we spoke long about serious domestic matters. He stayed with us for dinner. Come dusk we were joined by Bronisław Zaleski and Cypryan Norwid. We then moved to my apartment and the discussion turned to the past and the future of our homeland. Mierosławski offered explanation regarding the accusations he faced, speaking with greater gravity than that one time before Branicki, and was visibly moved. Bronisław attacked him

4 Cf. M. Zychowsкi, Generat klęski Ludwik Mierosławski, Warszawa 1965, pp. 79-83.

${ }^{5}$ Mierosławski travelled under the name Franciszek Szatkowski, or Majewski (M. ŻychowsKI, Generat klęski, p. 80). The question of Norwid's passport is a separate issue since it was also used by Maksymilian Jatowt and Michał Sadowski; see: Z. Trojanowiczowa, "Norwid w więzieniu berlińskim,” pp. 191-213.

${ }^{6}$ Z. Trojanowiczowa, Na wielkopolskim tropie, p. 155.

${ }^{7}$ Authors of Kalendarium note that "[p]erhaps in 1880, as Norwid was writing these words ["wojowałem troszkę" [I fought a little]] he wished to state that in this period [...] he would fight with words, publishing for example Pieśn spoleczna czterech stron [Four Directions Social Song] and Promethidion, also referring to the fame and sympathy won by those accused in the trial [of participants in preparations for the 1846 uprising under Prussian rule]," ibid., p. 271. 
boldly but tactfully, while Norwid and I supported him with warm compassion. If true, Norwid's anecdote about Kościuszko is beautiful and inspiring: Kościuszko would don a peasant robe after suffering immensely at the hands of the gentry and overcoming Gethsemane temptations, with all the religious ceremony, etc. The discussion continued until late... ${ }^{8}$

Mierosławski, who stayed in Paris at the time, was busy with organizing a Polish military academy and an officer school in Italy. ${ }^{9}$ The dispute between Mierosławski and Bronisław Zaleski, who supported the Czartoryski camp, probably regarded many issues, but the above-mentioned anecdote related by Norwid refers to the issue of peasant participation in national liberation and their status in free Poland. It remains ambiguous who Norwid and Zaleski were "compassionate" with, but the anecdote suggests sympathizing with Mierosławski, who worked on the republican programme and that of the Polish Democratic Society (TDP), which was close to Norwid, though not without reservations. At the same time, however, one could expect Norwid to polemicize with Mierosławski, especially with regard to the attitude towards aristocracy and the very idea of insurrection, which - as we know - Norwid opposed, all the more so since the topic of the Warsaw massacre of February 1861 must have been brought up. ${ }^{10}$

In September 1861, Norwid wrote - as Gomulicki termed it - a "summary of observations made in Poznańskie during the preparations for the 1846 uprising and directly after the fall of the 1848 uprising, meant for Józef Bohdan Zaleski" (PWsz VII, 645). After painting an ironic image of Europe at the time, which the poet accused of degrading "moral and political values," he offers the following characteristic of what happened in Poznańskie:

The Poznań movement is more and more lively although it lacks funding. No battlefield was scouted in advance and volunteers are led in such a way that they suffer wounds worse than in greatest battles. Women pin stars from gilded paper in their loosened hair and form clubs. There are no hospitals or sister nurses, which means that those who have been hurt die from minor wounds.

The Poznań province earns two ranks in history and social reality, owing to two men: the Prussian King, who liberated peasants, and Ludwik Mierosławski, who gave them spurs. (PWsz VII, 58-59)

${ }^{8}$ After: A. Krechowiecki, O Cypryanie Norwidzie. Próba charakterystyki, Lwów 1909, vol. 2, p. 139.

9 Cf. M. Zychowski, Generat klęski, pp. 215-219.

${ }^{10}$ Cf. G. Halkiewicz-Sojak, Norwid wobec idei insurekcyjnej-w świetle stanu badań, "Studia Norwidiana" 33 (2015), pp. 3-16. In this article the author wishes to explain the divergences among the critics with regard to Norwid's attitude towards the idea of insurrectionism, indicating the relationship between the poet's political ideas, his views about the past and the future, and current political events. 
During the conversation at Zaleski's, Norwid could thus express his views formulated in Poznańskie 1846-1848 regarding the poor preparation of both uprisings. If "fighting a little" with Mierosławski in 1846 was indeed a polemic with the general, it must have regarded the "untimely" character of the insurrection and the squandering of the insurrectionists' blood.

In 1863, probably in March (as Gomulicki argues; see: PWsz VII 658), i.e. after the January Uprising and still during the dictatorship of Mierosławski, Norwid wrote a political note addressed to August Cieszkowski, titled Philolect. The text assesses the state of the Polish press and calls for a fully-fledged Polish daily, discussing two figures: the Margrave of Wielopolska and Mierosławski, who are cited as examples of people condemned in "Dziennik Poznański". Defending them, Norwid argues that the former "serves neither for money nor for rank" (PWsz VII, 128), while the latter was "the first after Kościuszko to mobilize peasants to fight, and the one who prepared the insurrection from the ground up" (ibid.). Norwid explains their criticism as follows: "They have power because they abuse certain truths, which Polish patriots did not do" (PWsz VII, 129). The former is defended on the grounds that he was aware of the necessity to establish some relationship with Russia, regardless of circumstances, while the latter - due to his activity in preparing the uprising and his attitude towards peasants. The metaphor of "power derived from abuse" is rhetorically impactful, positively indicating that which - in terms of national liberation - Norwid saw as being disregarded by "the enlightened" among Polish politics, by "patriots and the kindliest passionate people." "Just like in physics," he writes, "vacuum becomes the centre of power" (PWsz VII, 129).

Norwid succinctly assesses Mierosławski as the author of De la nationalité polonaise dans l'équlibre européene (1856) in remarks titled O broszurze „Polska i panslawizm," which_regards an article published anonymously in Przeglad Poznański in 1857, as Gomulicki reports after Dionizja Poniatowska née Iwanowska (PWsz VII, 671). The poet accuses the author that she did not take the General's book into account in her argumentation. Norwid refers to him in the following words: "he shall elevate the peasant organism over the national substance and its church character (a noble patriot and victorious volunteer, indomitable yet suffering from exile!)" (PWsz VII, 187-188). This short passage offers both praise of the general and a polemic with ideas expressed in his book regarding the nature of the Polish organism, whose backbone was constituted the general argues - by democratic and revolutionary commoners. What Norwid thought the future dictator of the January Uprising missed was the idea of nation as an ethnic and religious organism - a concept that lies at the foundation of 
Norwid's perception of the Polish cause in the general European context. This particular remark by the poet does not refer to the entirety of Mierosławski's book, which means that it is impossible to deduce from it any polemicizing or approving points about the general's views, although Norwid was certainly supportive of Mierosławski's critical remarks about pan-Slavism, the role of Poland in reforming the Russian system and awakening the Russian people, and finally regarding the democratic peasant-rule in future Poland, although in this area Norwid would polemically "fight a little," speaking out in favour of tradition and respect for distinguished families. Perhaps Norwid would be also positively inclined towards Mierosławski's idea of using the French diplomacy of Napoleon III to settle the Polish question, which brought this project closer to the diplomatic activity of Hotel Lambert.

In April 1856 Norwid sent a letter to Mierosławski, thanking him for borrowing his book, probably referring to the aforementioned De la nationalité polonaise... ${ }^{11}$ : "I am curious," Norwid writes, "about the General's ideas regarding this direction - one that I find dear and serious" (DW XI, 57). The letter basically addresses one question, namely that of the encyclical published by Pope Gregory XVI under the title Cum primum (9 July 1832), which condemns the Polish struggle for national liberation. Norwid, who supported "legal power" and the principle of Rome's primacy, defends the Pope, blaming Polish diplomacy for lack of effort to explain in Vatican the rationale behind the November Uprising. A discussion of this constitutes the letter's first part, with the question "What is?" in the heading. Norwid's main argument is that contacts between Poland and Vatican have been neglected. He emphasises that "[i]f he [the Pope] was informed about recent events, it turned out that basically the last contact between the Polish parliament (the voice of the nation's soul) and Vatican occurred under Tsar Alexander, when it was only his support and will that prevented the legalization of divorce" (DW XI, 58). The second part of the letter, announced by the heading "What seems to me to be the case" is in fact a continuation of his criticism regarding diplomatic neglect. "Despite all its historical Christian merits," Poland forced others "to make guesses," unaware that extra effort is required to "make itself clearly visible." Such "propagandist" or - as he puts it - "vulgarizing" diplomacy does not concern the fame of "acting figures" but God's glory. Writing in 1856, Norwid revised the accusation of diplomatic neglect in order to bring to the attention of Mierosławski - a man of action - that intellectual work is necessary to lay the foundations for further undertakings. What we are dealing with here is, on the one hand, an indirect accusation that Mierosławski,

\footnotetext{
${ }^{11}$ This is also suggested by the authors of Kalendarium, p. 622.
} 
as a democrat, cut all ties with the Vatican, and on the other - a call on him to respect diplomatic activities in his political actions as a soldier and leader. ${ }^{12} \mathrm{At}$ this stage it is worth to recall that in April 1879 Norwid called Mierosławski (in a letter to Bronisław Zaleski) a "political agitator" (PWsz X, 130), probably not referring to his diplomatic talent, but rather to his oratory skills as an interlocutor, and primarily as a speaker addressing crowds, whom Władysław Mickiewicz called a "chirping jabber." 13

The most fascinating aspect of the relation between Norwid and Mierosławski concerns two notes addressed to the general in 1863. The first - O konieczności presji moralnej - was written in late May and sent to Mierosławski through Józef Bohdan Zaleski, because the former dictator of the January Uprising was hiding in Paris. A similar note was sent at the same time to Władysław Bentkowski. Gomulicki interprets Norwid's choice of addresses in the following way: the note to Bentkowski was addressed to the representative of "thought," while the note to Mierosławski - to the representative of "action" (PWsz VII, 659). The note to Bentkowski in fact proposes to influence Russia through an "intellectual organ" - a periodical established by the National Government, which would exert moral pressure on "the components of this state," preventing "negative patriotism in the Russian state" (PWsz VII, 131). In the note to Mierosławski, Norwid argues that the struggle for liberation cannot be based on "scythe-bearing peasant recruits only" because this would entail "many splendid episodes and the destruction of the country - a heroic fall" (PWsz VII, 133). It is necessary, he concludes, to exert pressure (as formulated in the note to Bentkowski) with the help of the press "on every component of the state individually" (ibid.). Recognizing Mierosławski as "a man of action," the poet stands up for the propagandist and diplomatic aspect of liberation, demanding that military action be coordinated with the work of intelligentsia, which he saw as worthily represented by Franciszek Duchiński.

In November Norwid wrote a second note to Mierosławski - Nota (z dziewięciu punktów) - which contains specific ideas of diplomatic actions aiming to summon an international military congress that could grant the Polish insurrectionists the rights of a "fighting party," identifying them as a regular army, as well as assess the methods used by the Tsar's army with regard to the insurrectionists. Norwid thought that calling such congress could offer a chance for moral revolution in Europe, which should be initiated by Polish journalists.

${ }^{12}$ Włodzimierz Torun claims that Norwid's argumentation "is not entirely convincing" since the poet's aim was rather to "reassure the author of these words"; IDEM, Norwid o Niepodległej, Lublin 2013, p. 184.

${ }^{13}$ W. Mickiewicz, Emigracya polska 1860-1890, Kraków 1908, p. 13. 
He argues that if Christianity-based military orders were dissolved in Europe, their place would be taken by armies "based on rewards, word of honour, and discipline" (PWsz VII, 149). In this way, he notes, Christianity allowed war to turn into a duel without any seconds, or in fact into armed robbery. The poet outlines procedures ("technical means") that would determine the assessment of actions taken by warring parties, beginning with the establishment of an "editing committee" that would prepare the right note with appropriate appendices, with the verdict being published in "official gazettes of European armies." Norwid does not specify the possible final outcome of these steps, but he probably intended to "civilize war" by establishing some kind of an international tribunal. Mierosławski was not the only addressee of this and other notes drafted by Norwid. Slightly amended versions were also sent to Karol Ruprecht and Władysław Zamoyski, representative of the National Government and Hotel Lambert diplomat, respectively. Together with Władysław Bentkowski they form a gallery of important Polish figures from decision-making and opinion-forming circles, which Norwid wished to convince to bring the Polish question to international attention, and make Polish insurrection a part of a broader revolutionary process in Europe based on Christian morality. He was aware that the Polish particularism in struggle for liberation, whether military or diplomatic, cannot be successful if it does not take into account the overall political situation on the continent. Thus, as he wrote to Kraszewski, the Polish cause should not base on the "pretence to exist" but on the "right to exist" (PWsz IX, 92). This would rely on making the European society aware not only that Poles have the moral right to their own country, but also that this right is based on the necessity for Poland to exist due to its significant contribution to the moral transformation of Europe and the entire humanity. ${ }^{14}$ The proposition to summon a military congress could be one such contribution to changing the world. If Norwid "fought a little" with Mierosławski with his notes, it was with the aim to expand the general's perception of the Polish cause and, in a sense, turn this representative of "action" into one of both "thought and action," turning the knight of Poland into a knight of Europe and the world.

In 1856 Norwid wrote the poem Pokój, which he dedicated to two generals: Józef Wysocki and Ludwik Mierosławski. Here is the full text:

${ }^{14}$ In version of the note addressed to Władysław Zamoyski Norwid writes that "every new nation has to bring something new and must be indispensable in some respect" (PWsz VII, 155). 


\author{
POKÓJ (WIERSZ) \\ Generałowi Józefowi Wysockiemu \\ i generałowi Ludwikowi Mierosławskiemu \\ przypisuje autor \\ 1856
}

Un homme obscur suivait la cour, nourri du pompeux espoir de découvrir un monde, il était triste dans la joie commune; il regardait avec indifférence et presąue avec mépris une conquête qui semblait dépasser tous les désirs. Cet homme était Christophe Colomb.

Traduit de 1'espagnol: Histoire contemporaine du roi Ferdinan

I

Lamp deszcz ognisty światu opowiada,

Że pokój nastał - że wzięta Grenada,

Że Maur ostatni, szablę zgiąwszy krzywą,

W gotowe kajdan zamienia ogniwo;

Że Ludzkość cała (bo Hiszpania cała),

Co była winna pragnąć, doczekała!...

II

Lamp deszcz ognisty trwał i śmiechy trwały,

A zapał owy tyle był namiętny:

W Ludzkości całej (bo w Hiszpanii całéj),

Że - jeden tylko człowiek obojętny,

Za dworem idąc, nie dzielił tej furii.

III

Był to niejaki Colomb... człek z Ligurii...

Pisałem 1856 r., 2 marca, w Paryżu (PWsz I, 238)

The poem references the historical fall of Granada on 2 January 1492 when the city was liberated from Muslim rule by the Christian Spanish army. The general joy of victory is illustrated by Norwid with a rain of fireworks ("lampy ogniste"), announcing peace to the world. The only person who does not partake in jubilation is Christopher Columnus ("człek z Ligurii" [man from Liguria]), who - as we learn from the motto - is "sad among the general rejoicing." Wiktor Mikucki explains his sadness by arguing that the future discoverer of America was regarded by Norwid as "the embodiment of a wronged and rejected genius"15 and a man capable of perceiving current affairs from a broader, more universal and worldly perspective since he was already planning his bold journey in search of

${ }^{15}$ W. MiKUCKI, Komentarz polityczny do wydarzeń z wojny krymskiej w miniaturze dramatycznej ,, Teatr bez teatru” $i$ wierszu „Pokój”, [w:] Trudny Norwid, red. P. Chlebowski, Lublin 2013, p. 300. 
the New World, which began in October 1492, several months after the liberation of Granada. One could thus assume that Norwid used the figure of Columbus to introduce himself as the observer of contemporary events, regarding them from a universal perspective, and feeling bitter due to lack of appreciation. Considered in this light, the poem invites one to draw universalist conclusions, which - due to being addressed to Mierosławski - offered to expand his perception of current political events.

As commentators suggest, the date at the end of the poem should be also treated as significant because it introduces an important context. On 2 March 1856 it was already clear that the Crimean War was ending and preparations were underway in Paris before signing the peace treaty on 30 March. Norwid learned about the outbreak of this war in America and decided to return to Europe to join the struggle due to its Polish aspect. ${ }^{16}$ War in Crimea rekindled the hope to settle the Polish question through diplomatic efforts undertaken by émigré circles and Polish participation in the anti-Russian coalition. Both Hotel Lambert and the Polish Democratic Society decided to organize a Polish formation to fight alongside the Turks. ${ }^{17}$ However, a dispute concerning competences ensued. The democrats would not agree to Czartoryski's role as the "nation's commander." ${ }^{18}$ Soon there was also discord between the two addressees of the notes: Mierosławski and Wysocki. As Marian Żychowski writes, “[d]uring Wysocki's absence, Mierosławski would begin to take arbitrary actions regarding Koło [Towiański's Circle of God's Cause] and its members, creating the illusion of 'double rule' but in fact wishing to get rid of Wysocki. [...] Mierosławski used his name to initiate a political game in order to gather the entire émigré society under his wing." ${ }^{19}$ Thus, in the shadow of the Crimean War, two émigré wars were fought, which constitutes the context of the poem "Pokój," whose original background involves mediation in order to bring peace to the two feuding sides of the émigré dispute. Adopting "Columbian" intellectual distance, Norwid brings to the attention of both generals that this is no time for "lamp deszcz ognisty" [a fiery rain of lamps] because the Paris peace treaty ending the Crimean War did not settle the Polish question; even worse - it

${ }^{16}$ Cf. W. Weintraub, Czy Ameryka była dla Norwida infernem?, „Kultura” (Paryż) 4 (1963), pp. $43-44$.

${ }^{17}$ Count Władysław Zamoyski would carry out this mission on the part of Hotel Lambert, while General Józef Wysocki - in the name of the democrats.

${ }^{18}$ In his monograph on Czartoryski Jerzy Skowronek writes that Prince Adam wished to be "the commander of the nation like Washington", TenżE, Adam Jerzy Czartoryski 1770-1861, Warszawa 1994, p. 493.

${ }^{19}$ M. Zychowski, Generat klęski, p. 197. 
complicated the situation of Poland by moving it into the shadow of other matters preoccupying European diplomacy.

On 6 February 1864 Norwid wrote thus in a letter to Marian Sokołowski:

It is convenient to grumble about the fact that Europe is not launching a crusade, but one ought not to have broken the Catholic or humanitarian whole into a pantheon of nations.

WHERE SHOULD PETER THE HERMIT GO TODAY - AND TO WHOM?... to national egoisms, which shattered the humanitarian whole [...]. (PWsz IX, 129)

This remark follows his critical mention of Mickiewicz, whom Norwid refused to regard as a national poet, calling him instead "exclusive" and arguing that "[n] ational authors are ones in whose works the nation occupies the kind of position that reflects the role it plays in the development of history and humanity" (PWsz IX, 128). As has been customarily interpreted, the crusade mentioned in the letter is a reference to Mickiewicz's project of a national crusade, which recurs in his works from Ksiegi narodu i pielgrzymstwa [The Books and the Pilgrimage of the Polish Nation] to the Paris lectures, and also informed his Towianist activities and journey to Turkey, which ended with his death. In the conclusion to the study titled Adam Mickiewicz i ostania krucjata. Studium romantycznego millenaryzmu ${ }^{20}$ Janusz Ruszkowski suggests that Norwid's remark about the crusade could also refer to Mierosławski, who exhorted the young generation of émigrés (in the address Do młodego pokolenia delivered on the twenty-eighth anniversary of the November Uprising) to "march on towards the Holy Sepulchre of Poland." In his speech, the General called:

And you, leaders of Piast's peasants, young crusaders shining bright over the dark masses like glimmers of night guiding to the Holy Sepulchre, remember that the path towards it is determined by neither blind frolic nor presumptuous calculation. You will not reach it - O, the noisy yet barefoot and unarmed masses of Peter the Hermit - through usurers or pawnshops sold to the Byzantine Tsar. Nor shall you reach it - O gullible knights, nosy Baldwins and Bohemonds - if you keep looking among the thrones of Edessa and Antioch whether Christ did not lose something there. But you shall reach your destination - $\mathrm{O}$ disciplined regiments of crusaders - if you follow straight ahead, through heaps of Saracen bodies, like Gottfried who would not leave any possessions behind, melting all into armour; Gottfried who would renounce any golden or laurel crowns, pushing them off of his bloodied forehead in order to cling to one crown only, kneeling by the Holy Sepulchre - the only true crown, that of thorns $!^{21}$

Mierosławski does not say that Gottfried is Mickiewicz but he himself - he is supposed to lead a crusade of the young to the holy motherland in order to win

${ }^{20}$ J. Ruszkowski, Adam Mickiewicz i ostania krucjata. Studium romantycznego millenaryzmu, Wrocław 1996.

${ }^{21}$ After: ibid., p. 252. 
it back and resurrect it. Ruszkowski additionally suggests that in the general's speech Peter the Hermit would be Mickiewicz, while Baldwin and Bohemond - Czartoryski and Władysław Zamoyski, respectively. Mierosławski's crusade would thus pose an alternative to the émigré politics of the Towianists and Hotel Lambert. In the letter to Sokołowski, Norwid is critical of both émigré relations and the situation in Poland, which he saw as not ready for liberation yet, among other reasons due to the lack of an intelligentsia that would take the burden of organizing state life. Ruszkowski provides the following commentary to Norwid's criticism:

Perhaps in the quoted letter Norwid did not mean Mickiewicz but Mierosławski, for example, whose embarrassing participation in the January Uprising he must have remembered. Perhaps endeavours like Mierosławski's crusade appeared to him as a caricature of ideas developed by Mickiewicz. Perhaps he thought that poets are in fact responsible for caricatures of their own ideas. ${ }^{22}$

One could assume that Norwid criticises both Mickiewicz, rejecting his claim to the status of a universal poet and treating him as a poet of Polish particularism, and Mierosławski, with whom he would "fight a little" (however we understand this), primarily attacking the very idea of a nineteenth-century crusade. Norwid would probably agree on this with his adversary Julian Klaczko, who ridicules Mierosławski in Katechizm nie-rycerski (1859), arguing that "this is no way for a statesman to speak, nor for a leader of regiments or, even less so, for Gottfried the crusader, whom Mr Mierosławski honours (if I understand correctly), rather unjustly and undeservingly, by comparing him to himself. ${ }^{, 23}$ This was further augmented by the fact that in his speech Mierosławski opposed social and economic reforms in Poland, while the religious aspect of the general's crusade must have appeared as blasphemous to Norwid, just like the Towianist ideas of Mickiewicz.

Norwid's answer to Mierosławski's protest against Prince Czartoryski deserves to be discussed separately due to the weightiness of this issue. In November 1854 Norwid wrote, in a letter to Wincenty Mazurkiewicz, that

[...] having read the protest letter against the faction of Prince Czartoryski, I should inform you in advance that I shall not sign it. Further, if it is deemed necessary, please forward the explanation of my intentions to General Mierosławski.

1. Protests are inseparable from weakness and helplessness - they are the last resort left to the defeated and not to those who set out to fight. Only when one is down and broken, and has nothing left, can they begin to protest. During games in Sparta, a wrestler thrown to the gro-

\footnotetext{
${ }^{22}$ Ibid., p. 256.

23 After: ibid., p. 253.
} 
und would lift two fingers in protest when this was all he could do. Protest comes at the end, not at the beginning.

2. Because this is the moral value of protests, so is their practical dimension, e.g. Prince Czartoryski has recently withdrawn any personal pretences and asks that people authorize him with their signatures to work "only towards the liberation of Poland." And now demands are made to sign a protest letter against him - and maybe tomorrow the same means will be mobilized by Nicholas I to protest against amnesty. All of this can be equal because of being based on signatures and individual criticism. (DW X, 531)

The protest letter against Czartoryski titled Oświadczenie emigrantów polskich was signed on 10 November 1854; it was also printed by the Prince as Okólnik in order to inform the general public "so that all those who do not share his deeply patriotic feelings, full of Christian love, can learn more about his views and proposed means of action." ${ }^{24}$ Mierosławski's protest letter accuses both the Czartoryski family (using the term "Czartoryszczyzna") and Prince Adam himself of "betrayal and losing their national identity": "this family and its entire train is malevolent, ceaselessly being a flunky to the Moscow regime, enriching itself on the ruins of national hopes." The many accusations include: cultivating ties to Catherine II and her interests to the detriment of the Polish nation, striving to make Poland a "Tsarist province or vassalage," betraying the country by joining Targowica, altering the political approach under the influence and disfavour of Tsar Nicholas, acting against the November Uprising (Mierosławski emphasises the negative role of Władysław Zamoyski, who "disarmed the uprising" by appropriating a part of the armed forces to realize his own interests), and finally impeding diplomatic activities after the fall of the uprising. Mierosławski concludes by accusing Hotel Lambert of striving to disperse the Polish emigration, causing it to become morally corrupt, adopting the harmful policy of organizing a Polish legion in Turkey, and presenting a false image of the ambitions developed by the Polish emigration and the entire suffering nation.

In his letter to Mazurkiewicz, Norwid neither directly refers to the accusations levelled against the Prince by Mierosławski, nor defines his approach to the diplomatic activities of Hotel Lambert. The poet would not enter a discussion with Mierosławski, or address the accusations of securing only private family interest and appropriating Poland. He does not refer to monarchist ambitions, diplomatic efforts aimed at pacifying revolutionary energy, or claims that the Prince contributed to the putting down of the November Uprising. He would not comment on the anti-democracy and the aspirations to revive and maintain the political system

${ }^{24}$ Okólnik (w sprawie reorganizacyi Towarzystwa Demokratycznego z Projektem prete- stacji przeciwko działaniu Czartoryszczyzny), http://jbc.bj.uj.edu.pl/dlibra/plain-content?id= 57236 (accessed 16 October 2015). 
from before the partitions. Further, he does not address the engagement of Polish émigré forces in struggles where Poland had nothing at stake. Finally, he did not directly comment on the participation of Poles in the Crimean War. It was more important for him to negatively assess the very character of protest as a means of political competition.

Norwid could not sign Mierosławski's protest because he would not place himself in the position of the weaker, losing party. Still, this was not a personal matter but a question of the essence, meaning, and direction of the Polish emigration. In the next letter to Mazurkiewicz (written in the autumn of 1854 or the winter of 1855, according to Gomulicki), he explains in the context of Mierosławski's attempts to reform Polish emigration politics that "all nations gave birth to passive emigrations" (DW X, 536). He also ascribes this kind of passivity to the Polish emigration, which is additionally internally split and can at best write letters of protest instead of raising awareness about "human rights" and subordinating Polish politics to spreading them, a politics formulated in the Polish language yet derived from sentiments common to the entire humanity (DW X, 537).

$* * *$

Who was Mierosławski to Norwid? A "personal seriousness," as he put it in O polskiej władzy prawowitej [On the Rightful Polish Government] (PWsz VII, 167), which would mean that he was important for at least two reasons. The first would be connected with the place occupied by the general in the social and political life in Poland and Europe at the time. He was a man of action, a militarist competent enough to realize plans of national liberation with the help of his martial expertise, leadership skills, and strategic talent. He was able to tie the struggle for independence with the necessity to reorganize society in such a way as to modernize it and combine all of its classes into one robust organism capable of winning back and maintaining independence (although Norwid would disagree with certain specific propositions formulated by Mierosławski). The second reason stems from the first and is connected with the necessity to reconcile the energy of action with that of thought. Thus, Norwid regarded Mierosławski as a person capable not only of leading a successful military campaign, but also of combining it with the art of diplomacy and - to employ a contemporary term - propaganda. He would thus try to convince Mierosławski to use the press to influence the public opinion both in Poland, to transform the mindset of his compatriots, and abroad, in relation to a broader, European consciousness, which he would subordinate to the categories of Christian universalism.

Mierosławski failed both of these expectations defined by Norwid, as a result of which they had to "fight a little." 


\section{REFERENCES}

Halkiewicz-Sojak, G., Norwid wobec idei insurekcyjnej - w świetle stanu badań, "Studia Norwidiana" 33 (2015), pp. 3-16.

Krechowiecki A., O Cypryanie Norwidzie. Próba charakterystyki, Lwów 1909.

Mickiewicz W., Emigracya polska 1860-1890, Kraków 1908.

MiкUсKI W., Komentarz polityczny do wydarzeń z wojny krymskiej w miniaturze dramatycznej 'Teatr bez teatru' $i$ wierszu 'Pokój', [in:] Trudny Norwid, ed. P. Chlebowski, Lublin 2013.

Okólnik (wsprawie reorganizacyi Towarzystwa Demokratycznego z Projektem pretestacji przeciwko działaniu Czartoryszczyzny), http://jbc.bj.uj.edu.pl/dlibra/plain-content?id= 57236 (accessed 16 October 2015).

Ruszkowski J., Adam Mickiewicz i ostania krucjata. Studium romantycznego millenaryzmu, Wrocław 1996.

SkowroneK J., Adam Jerzy Czartoryski 1770-1861, Warszawa 1994.

Toruń W., Norwid o Niepodległej, Lublin 2013.

Trojanowiczowa Z., DambeK Z., Kalendarium życia i twórczości Cypriana Norwida, vol. 1, Poznań 2007.

Trojanowiczowa Z., Na wielkopolskim tropie Norwida, [in:] IDEM, Romantyzm. Od poetyki do polityki, eds. A. Artwińska, J. Borowczyk, P. Śniedziewski, Kraków 2010, pp. 147-190.

Trojanowiczowa Z., Norwid w więzieniu berlińskim, [in:] IDEM, Romantyzm. Od poetyki do polityki, eds. A. Artwińska, J. Borowczyk, P. Śniedziewski, Kraków 2010, pp. 191-213.

Weintraub W., Czy Ameryka była dla Norwida infernem?, "Kultura” (Paryż) 1963, no. 4, pp. 43-44.

Zychowski M., Generał klęski Ludwik Mierosławski, Warszawa 1965.

\section{$\mathrm{S}$ u m m a r y}

This article discusses the relations between Cyprian Norwid and General Ludwik Mierosławski, participant in national uprisings, leader of the January Uprising, and an activist in exile, presenting their personal contacts and Norwid's opinions voiced in literary works, letters and journalism. These opinions encompass his support for democratic ideas proclaimed by the general and critical statements. While appreciating Mierosławski as a militarist and a man of action capable of implementing policies intended to transform the mindset of the Polish public to facilitate building a modern state, the poet expected that his activity would be subordinated to a superior idea, which, owing to its Christian foundations, would indicate the path to independence. He demanded that Mierosławski recognize the primacy of thought over action, that journalism be used to influence the public opinion, both in Poland and around Europe, and that measures be developed to dismantle political barriers existing within the émigré community.

Keywords: Norwid; Mierosławski; Romanticism; the struggle for national liberation; political discourse

SŁAWOMIR RzePCZYŃSki is Professor at the Pomeranian University in Słupsk, and editor-inchief of the magazine Świat Tekstów. Rocznik Slupski. His publications include Krytyka literacka w twórczości Norwida. Próby ujęcia (1998), Biografia i tekst. Studia o Mickiewiczu i Norwidzie (2004), Wokół nawel ,włoskich” Norwida (2006), and O Norwidzie. Syntezy i zbliżenia (2017); e-mail: slawrz@poczta.onet.pl. 